\title{
Editorial: Advances in Understanding Megaliths and Related Prehistoric Lithic Monuments
}

\author{
G. Terence Meaden \\ Oxford University Department of Continuing Education (Archaeology), and Kellogg College, Oxford \\ University, 62 Banbury Road, Oxford, U.K. Email: terencemeaden01@ gmail.com
}

Standing stones and megalithic monuments are impressive remains from a remote prehistoric world that for the British Isles began some 6000 years ago and led to a cultural flowering that peaked in the Late Neolithic and Early Bronze Age with the rise of fine megalithic monuments like Newgrange, Knowth, Drombeg, Maeshowe, Avebury and Stonehenge. Nearby on the European continent, what may be called an era involving megalithic culture had begun a few centuries earlier (as at Carnac and Locmariaquer), and still earlier in the Mediterranean lands and islands (e.g., the Tarxien Temple in Malta), southeastern Europe, the Near and Middle East, and India beyond.

Antedating and contemporary with the well-known grand megalithic edifices, many thousands of lesser monuments were built worldwide using standing stones in the form of the first chambered long barrows, court tombs and allées couvertes. Preceding them, it is likely that a range of simpler constructions would have been raised such as single standing stones and perhaps the first stone rows or dolmens, most of which have left little evidence for us to date them. Erection of single stones and stone settings like these continued for many centuries, and after 3000 B.C.E. stone circles became numerous in Britain and Ireland. Unhappily, and perhaps relatively quickly towards the middle of the second millennium B.C.E., the European Megalithic Age was ending and knowledge of the purposes and uses of the megalithic monuments came to be lost.

Since then, many prehistoric settings and monuments have disappeared forever, but we may be grateful for those that survived despite their battered condition caused by extremes of weather, lack of maintenance, human misunderstanding, and, for some, landscape or sea-level changes. Another misfortune is that the builders in their illiteracy left nothing in writing about the meaning and use of their much-loved constructions, although occasionally there are clues by way of associated finds of bones, pottery, grave goods, artifacts and artwork, and, it should be noted, various clues in the form of lithic symbols, images and alignments. It is further helpful that in some parts of the world, including India and Madagascar, megaliths continue to be raised to this day - for this permits interviews with tribal devotees. In the Americas too one can discuss current understandings with descendant natives about ancestral rites, functions and traditions. ISSN: 2055-0472. URL: http://journals.ed.ac.uk/lithicstudies/

This work is licensed under a Creative Commons Attribution 2.5 UK: Scotland License. 
In this issue of the journal the attention of some authors has been directed at symbols and images that have been incorporated into the structural detail of the lithic settings under review. These authors and others have noted how some arrangements, in part or in whole, were sited in the landscape to align with cosmic features, particularly the points of sunrise for certain dates of the year, and, for a few, with solar settings. Additionally, there are stones that were selected for their shape, or had their shape modified, or carvings sculpted on them. Overriding everything is the perception that the mentality that led societies to shift great megaliths was a susceptibility to acquire beliefs and fears in a world of danger and uncertainty in which people eternally struggled with the troubling realities upon which agricultural success depended. Above all, there were the vicissitudes of inconstant weather and land fertility that led to endless hope that they could be controlled through religious observance and practice.

This study reports advances in matters that lead to an improved understanding of the reasons why stones were so important in the lives of megalithic societies, and that sometimes parallels appear in faraway continents despite a lack of interaction by human contact. It is thought this may be due to factors emanating from the psyche, resulting in comparable views of aspects of Nature and the Cosmos related to life, gender and fertility.

The first paper is an in-depth study of the stones of the Drombeg circle in the west of County Cork in Ireland. A new survey of the stones, together with knowledge of the precise directions of sunrise, reveals couplings between stone pairs that were planned into the lithic layout but had not been noticed or appreciated in modern times - in fact not even witnessed since the last users of the stone circle in the Bronze Age. Each coupling is by shadow between pairs of standing stones that offer male or female features. Every time the shadow from a nominally male stone falls upon either one or other of two female stones - moreover this was arranged to happen "always at sunrise" on particular dates of the year. Photographic proof is presented. The primary purpose appears to be calendrical because encoded in the planning of the stones are the eight traditional dates of the agricultural year 45 or 46 days apart commencing with the winter solstice.

Similar interactions that involve shadow casting at sunrise take place at Knowth, Newgrange, Avebury and Stonehenge. At Avebury, as at Drombeg, stones are positioned such that the dates of the known traditional agricultural festivals are deliberately built into their structures. At Knowth the principal celebrations take place close to the equinoxes, at Newgrange at the winter solstice sunrise, and at Stonehenge primarily at the summer solstice sunrise and (this is a new discovery) the winter solstice sunrise. Avebury and Stonehenge are treated in a second paper in this issue of the journal.

Next, Dr. Kate Prendergast considers aspects of near-equinoctial events at sunrises and sunsets at the great megalithic monument of Knowth. Consideration is given to problems stemming from the non-matching of 28 or 29-day cycles of the moon with the annual cycle of the sun. Was there a Neolithic attempt to correlate varying lunar-solar timings in the region of the equinoxes several millennia before the calendrical problems that concerned the JudeoChristian moveable feast of Easter?

The studies in North America by Herman Bender in the state of Wisconsin are valuable for the rediscovery of landscape stone-patterning of a type called petroforms or lithoforms. This is the careful positioning of stones in order to create on the surface of a chosen terrain images in outline produced by placed stones as seen from above. The stone setting called 'Starman' exemplifies this well. It echoes Indian folk tales of a human body image on the landscape that repeats the tribally perceived image of a man among the stars of the celestial vault. The idea may also embody the perception that stones in the landscape whether natural or artificially positioned internalize a supernatural 'spirit', and were therefore sacred. 
Drs. Cicilloni and Cabras consider the landscape positioning of 90 dolmen structures of various types in the middle of Sardinia using GIS methodologies that embrace viewshed and cost surface analysis. This may lead to improved interpretations as to what particular placements had meant to the dolmen planners.

A major target is to understand some of the practical factors and spiritual thinking that were held by communities in the prehistoric world - and why.

For Britain and Ireland, the last of the peoples who knew about such matters had died by about 1500 B.C.E. when the megalithic monuments came to be abandoned at around what is commonly taken as the transition from the Early Bronze Age to the Middle Bronze Age. These peoples have long been dead. Such problems of prehistory are similar for the megalithic peoples of the continent of Europe and the Near East. By contrast, in the Americas and the subcontinent of India one can usefully interview surviving natives and tribal peoples and learn how significant that lithics in the landscape were to preliterate communities.

Further research and surveys by the editor have been achieved subsequent to the Drombeg project. Similar results were obtained at Bohonagh Stone Circle in County Cork and the first of the stone circles in north-east Scotland to be studied. The latter include the recumbent stone circles at Loanhead of Daviot, East Aquhorthies, Tyrebagger (Dyce), and Aikey Brae. All told, a considerable advance in knowledge of the archaeoastronomy of Neolithic and Early Bronze Age stone circles has been achieved. At these and other sites analyzed by the author the recumbent stone receives a medial shadow at the summer solstice from a carefully positioned megalith whose outline purposefully hints at male symbolism... and additionally at every monument there is a perimeter stone standing at the south-east that casts a shadow caused by the winter solstice rising sun on to a standing stone at the northwest classifiable as female. The visible stone-to-stone union is memorably striking. In every case shadow-casting stones have features that convey the concept of the male principle, while the receptive stones bear feminine symbolism. Because of their intelligent positioning these and other select stones take part in the annual round. In all, an eight-part calendar of the full year is represented, devised by the shrewdness and ingenuity of the astronomer-priests.

Some authors find that major features of the megaliths can be explained using concepts that invoke a belief scenario involving an Earth Mother and a Sky Father. It is well known that almost everywhere in the world when time and populations proceed from illiterate prehistory into recorded history, Earth Mothers or Mother Goddesses were widely present in documented legends and tales. This intimates that such divinities were likely present, too, in the preceding final stages of unwritten prehistory. Depending on which region of the world is treated, this transition to literacy took place in the Bronze Age or the Iron Age or later. Ultimately, aspects of religious belief appear to help explain how Stonehenge, Avebury, Drombeg, Knowth, Newgrange and Loanhead of Daviot among others were planned and built to exalt fertility notions at a high level of devotion.

Some stone arrangements further reveal positioning that suggests they were erected for fertility rites in which astronomy was helpful and for some of which necessary. In India among traditional customs of the tribals, the Sarhul continues to be an annual fertility festival in which an ancient belief of marriage between the Sky Father and Earth Mother is still upheld today, with the expectation that the fertility of farming lands and livestock is again renewed. In East India a similar fertility festival, three days long and known as the Ambabuchi, is celebrated at the summer solstice by Hindus. In North-East India where the practice of megalith erection after death endures, many such monuments are dedicated to Mother Earth.

All in all, the principal research thread was to evaluate the purposes and uses of standing stones, whether positioned singly or in settings, or whether raised as principal structural components in great monuments - and this with the further objective of advancing our 
knowledge of the lives of the communities worldwide that raised and used them. Access to existing native sources in North America and India have contributed towards a better understanding of the lithics and megalithics of Ireland, Britain and the continent of Europe.

G. Terence Meaden

Guest editor 